\title{
Assessment of ultrasound imaging and physical examination findings in greater trochanteric pain syndrome
}

\author{
Büyük trokanterik ăgrı sendromunda ultrasonografi ve fizik muayene bulgularının \\ değerlendirilmesi
}

\author{
Fulya Bakılan', Gökhan Yüce², Ahmet Çağdaş Bicen ${ }^{3}$, Kadir Serkan Yalçın ${ }^{4}$, Gökçe Tanyeri
}

\begin{abstract}
Objective: The aim of this study was to investigate the prevalence of greater trochanteric bursitis and gluteus medius tendinopathy using ultrasound in patients with greater trochanteric pain and assess the value of the pain on resisted hip abduction and pain on resisted hip internal rotation in predicting the presence of gluteus medius tendinopathy.
\end{abstract}

Methods: The study was a retrospective analysis of 75 patients with greater trochanteric pain. The physical examination records were identified as pain on resisted hip abduction and hip internal rotation. After observing physical examination records, presence of greater trochanteric bursitis or gluteus medius tendinopathy were assessed in documented ultrasound findings.

Results: Of the 75 patients with greater trochanteric pain, trochanteric bursitis was found in $41.4 \%$ of patients, gluteus medius tendinopathy was found in $20 \%$ of patients. A significant difference was found in both presence of pain on resisted hip abduction and internal rotation between patients with gluteus medius tendinopathy and patients with other abnormalities in favor of gluteus medius tendinopathy.

Conclusion: In order to determine the etiology of greater trochanteric pain, physical examination and ultrasound imaging is important, especially examination of pain on resisted hip abduction and hip internal rotation is essential to detect gluteus medius tendinopathy.

Key words: Bursitis, gluteus medius tendinopathy, greater trochanteric pain syndrome

\section{ÖZET}

Amaç: Bu çalışmanın amacı, büyük trokanter bölgesinde ağrısı olan hastalardaki trokanterik bursit ve gluteus medius tendinopati prevelansını ultrasonografi kullanarak belirlemek ve gluteus medius tendinopatisi tanısının konulmasında, dirençli kalça abduksiyonu ve iç rotasyonunda ağrı varlığının değerlendirilmesinin önemini belirlemektir.

Yöntemler: Bu çalışma büyük trokanterde ağrısı olan 75 hasta üzerinde retrospektif analiz ile gerçekleştirilmiştir. Hastaların fizik muayene kayıtlarında dirençli kalça abduksiyon ve iç rotasyonda ağıı varlığı araştırılmıştır. Fizik muayene kayıtlarının analizinden sonra hastaların kas iskelet sistemi ultrasonografi görüntüleme kayıtları incelenmiş olup, trokanterik bursit ve gluteus medius tendinopati varlığı değerlendirilmiştir.

Bulgular: Büyük trokanterde ağrısı olan 75 hastanın; \%41,4'ünde trokanterik bursit, \%20'sinde gluteus medius tendinopatisi saptanmıştır. Dirençli kalça abduksiyonu ve iç rotasyonunda ağrı varlığı, gluteus mediusta tendinopati saptanan ve saptanmayan hastalarda gluteus mediusta tendinopati lehine, istatistiksel olarak belirgin farklı bulunmuştur.

Sonuç: Hastalarda büyük trokanter ağrısının etyolojisinin aydınlatabilmesinde fizik muayene ve ultrasonografi ile görüntüleme önemlidir, özellikle dirençli kalça abduksiyonu ve iç rotasyonunda ağrı varlığının değerlendirilmesi, gluteus mediusta tendinopati varlığının saptanmasında gereklidir.

Anahtar kelimeler: Bursit, Büyük trokanterik ağrı sendromu, Gluteus medius tendinopatisi

\footnotetext{
${ }^{l}$ Department of Physical Medicine and Rehabilitation, Yerkoy/Yozgat Public Hospital, Yozgat, Turkey

${ }^{2}$ Department of Department of Radiology, Yerkoy/Yozgat Public Hospital, Yozgat, Turkey

${ }^{3}$ Department of Department Of Orthopaedic Surgery And Traumatology, Yerkoy/Yozgat Public Hospital, Yozgat, Turkey

${ }^{4}$ Department of Department of Internal Medicine, Yerkoy/Yozgat Public Hospital, Yozgat, Turkey

${ }^{5}$ Department of Department of Otorhinolaryngology, Yerkoy/Yozgat Public Hospital, Yozgat, Turkey
}

Yazışma Adresi /Correspondence: Fulya Bakilan,

Yerkoy Devlet Hastanesi Fiziksel Tıp ve Rehabilitasyon Bölümü Email: fulyabakilan@gmail.com

Geliş Tarihi / Received: 21.01.2015, Kabul Tarihi / Accepted: 26.02.2015

Copyright @ Dicle Tıp Dergisi 2015, Her hakkı saklıdır / All rights reserved 


\section{INTRODUCTION}

Greater trochanteric pain syndrome is a common cause of hip pain due to greater trochanteric bursitis or other diagnoses, such as gluteus medius tendinopathy, mostly peaks between the fourth and sixth decades of life in women [1-3]. The underlying mechanisms are multifactorial as mechanical, degenerative causes. Because the gluteus medius and minimus muscles stabilize the hip and are involved in externally rotation of hip, it may be associated with degenerative processes like shoulder rotator cuff muscles $[4,5]$.

The symptoms are pain over the lateral aspect of the hip with walking, and tenderness over the upper part of the femur [6]. Patients are sometimes misdiagnosed as many other pathologies of the nearby structures or as pain referred from the lumbar spine. Accurate diagnosis is important in relief of symptoms because the treatment varies depending on the cause. Ultrasound is a simple inexpensive and radiation free test that has been used to demonstrate tendinopathy and bursitis $[7,8]$.

The purpose of this study was to investigate the prevalence of greater trochanteric bursitis and gluteus medius tendinopathy using ultrasound in patients with greater trochanteric pain and assess the value of pain on resisted hip abduction, and pain on resisted hip internal rotation in predicting the presence of gluteus medius tendinopathy.

\section{METHODS}

The study was a retrospective analysis of all cases of patients with greater trochanteric pain seen at Department of Physical Medicine and Rehabilitation and Department of Orthopedics in Yerkoy State Hospital (Yozgat, Turkey) between March 2014 and January 2015 by searching the computerized database and patient files. The medical records of 75 patients were reviewed for age, gender, clinical findings, hip radiographs, ultrasound findings.

Patients $(n=75)$ aged 25-85 years with a complaint of greater trochanteric pain or tenderness for at least 6 weeks and patients who have physical examination records, hip radiographs and ultrasound findings reports, included to the study. Patients with pregnancy, rheumatic diseases, morbid obesity, cortisone injection in the affected hip in the previous 3 months, history of surgery, trauma, avascular ne- crosis, arthroplasty and infection in the affected hip were excluded.

The physical examination records were identified as pain on resisted hip abduction and hip internal rotation as predictors of a gluteus medius tendinopathy. Recent hip radiographs were evaluated by one musculoskeletal radiologist to exclude other causes of hip pain such as fracture, avascular necrosis and arthrosis.

After detecting physical examination records and evaluation of x-ray, musculoskeletal diagnostic ultrasound finding reports were detected. Ultrasound were performed by the same radiologist who works in the same hospital for 2 years with five years of musculoskeletal ultrasound experience using an Aloka Prosound Alpha 7 machine with a $12-\mathrm{MHz}$ linear probe (Aloka, Tokyo, Japan). In ultrasound finding reports, synovial thickening, anechoic or hypoechoic fluid in the greater trochanteric bursa defined as greater trochanteric bursitis; a thickened heterogeneous tendon with loss of the fibrillar pattern with or without intratendinous calcifications, enthesophytes, or tears defined as gluteus medius tendinopathy.

\section{Statistical Analysis}

Results were expressed as mean plus/minus standard deviation or median (range) values for all continuous variables. Differences subjects were assessed using the Chi-square test. $\mathrm{P}<0.05$ was considered statistically significant. All statistical analyses were performed using the SPSS program version 15.0 (SPSS Inc., Chicago, Ill., USA)

\section{RESULTS}

A total of 75 patients (15 male, 60 female) with a mean age of $57.08 \pm 12.91$ years were assessed. Trochanteric bursitis was found in $41.4 \%$ of patients, as for gluteus medius tendinopathy (figure 1,2), it was found in $20 \%$ of patients; only tendinopathy was found $16 \%$ of patients, tendinopathy with trochanteric bursitis was found $4 \%$ of patients (Table 1 ).

Pain on resisted hip abduction was found $45.1 \%$ of patients with trochanteric bursitis, $86.6 \%$ of patients with gluteus medius tendinopathy, $20.6 \%$ of patients with no bursitis or tendinopathy. Pain on resisted hip internal rotation was found $35.4 \%$ of 
patients with trochanteric bursitis, $80 \%$ of patients with gluteus medius tendinopathy, $13.7 \%$ of patients with no bursitis or tendinopathy. A significant difference was found in both pain on resisted hip abduction $(\mathrm{p}<0.001)$ and pain on resisted hip internal rotation $(\mathrm{p}<0.001)$ between "patients with gluteus medius tendinopathy" and "patients with no bursitis and tendinopathy". Also a significant difference were found between "patients with gluteus medius tendinopathy" and "patients with trochanteric bursitis" found in both physical examinations $(\mathrm{p}<0.05)$. A significant difference was not found in pain on resisted hip internal rotation between "patients with trochanteric bursitis" and "patients with no bursitis and tendinopathy" ( $\mathrm{p}>0.05)$. However a significant difference was found in pain on resisted hip abduction between "patients with trochanteric bursitis" and "patients with no bursitis or tendinopathy" $(\mathrm{p}<0.05)$ (Table 2).

Table 1. The demographic characteristics and ultrasound findings in patients with greater trochanteric pain

\begin{tabular}{lc}
\hline & Patients $(\mathrm{n}=75)$ \\
\hline Age (year) & $57.08 \pm 12.91$ \\
Gender (female/male) & $60 / 15$ \\
Only trochanteric bursitis (n) (\%) & $31(41.4)$ \\
Gluteus medius tendinopathy (n) (\%) & \\
$\quad$ Only tendinopathy & $12(16)$ \\
$\quad$ With trochanteric bursitis & $3(4)$ \\
No bursitis or tendinopathy $(\mathrm{n})(\%)$ & $29(38.6)$ \\
\hline Total $(\mathrm{n})(\%)$ & $75(100)$ \\
\hline
\end{tabular}

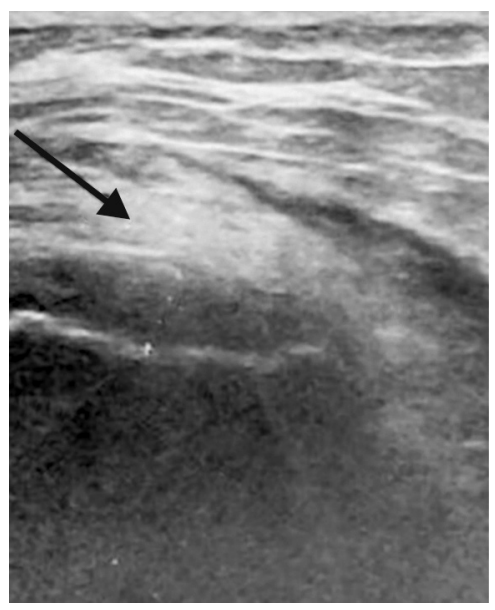

Figure 1. Gluteus medius tendinosis ultrasound images of long axis to lateral facet of greater trochanter show thick and hypoechoic gluteus medius tendon (arrow) with loss of normal fibrillar pattern and mucoid degeneration.

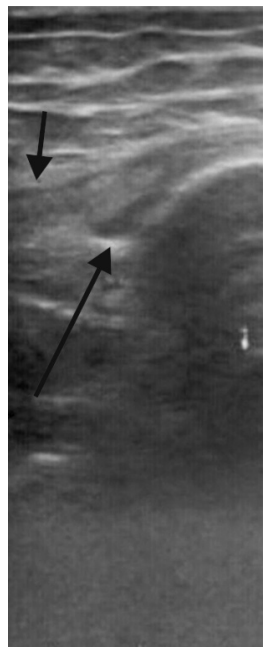

Figure 2. Gluteus medius tendinosis with bursal effusion ultrasonography images long axis to greater trochanter show tendinosis of the gluteus medius insertion (below arrow) with loss of echogenicity due to edema and mucoid degeneration. There is also a minimal effusion in the trochanteric bursa (upper arrow).

Table 2. Comparison of the presence of each physical finding between patients with trochanteric bursitis, gluteus medius tendinopathy and no bursitis or tendinopathy

\begin{tabular}{lccc}
\hline & $\begin{array}{c}\text { Trochanteric bursitis } \\
(\mathrm{n})(\%)\end{array}$ & $\begin{array}{c}\text { Gluteus medius } \\
\text { tendinopathy }(\mathrm{n})(\%)\end{array}$ & $\begin{array}{c}\text { No bursitis or } \\
\text { tendinopathy }(\mathrm{n})(\%)\end{array}$ \\
\hline Pain on resisted hip abduction & $14(45.1 \%)^{*}$ & $13(86.6 \%)^{* *}$ & $6(20.6 \%)^{* * *}$ \\
Pain on resisted hip internal rotation & $11(35.4 \%)^{\dagger}$ & $12(80 \%)^{\dagger \dagger}$ & $4(13.7 \%)^{++\dagger}$ \\
\hline Total & $31(100 \%)$ & $15(100 \%)$ & $29(100 \%)$ \\
\hline
\end{tabular}

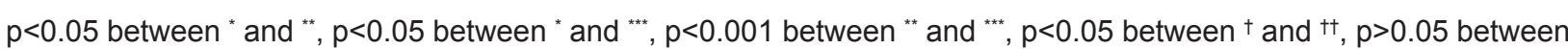
${ }^{\dagger}$ and ${ }^{\mathrm{tt}}, \mathrm{p}<0.001$ between ${ }^{\mathrm{t}}$ and ${ }^{\mathrm{tt}}$

\section{DISCUSSION}

Accurate diagnosis is important in greater trochanteric pain. The pain may result from greater trochanteric bursitis, gluteus medius tendinopathy, iliotibial band disorders [9] or may be referred pain such as, knee osteoarthritis, and low back pain [10]. The treatment varies depending on the cause. The therapy modalities of greater trochanteric bursitis or gluteus medius tendinopathy include physiotherapy, nonsteroidal antiinflammatory medication, and local injection of corticosteroids [11]. 
The most important step in the diagnosis is the anamnesis and physical examination. In our study pain on resisted hip abduction and hip internal rotation were investigated retrospectively in patients. Both tests were found positive in majority of patients who have gluteus medius tendinopathy. Our results were similar to previous studies, in a study, the ratio of pain on resisted hip abduction was found $65 \%$ in patients who have gluteus medius tendinopathy in magnetic resonance imaging [12]. To determine the etiology of greater trochanteric pain, physical examination is important, especially examination of pain on resisted hip abduction and hip internal rotation is essential to detect gluteus medius tendinopathy.

An imaging method is needed for differential diagnosis of greater trochanteric pain, ultrasound is established as an essential tool for the greater trochanteric pain syndrome. Ultrasound is significantly important for characterizing tendon abnormalities, demonstrating fluid in the bursa at the greater trochanter [9,13-15]. In our study, we found trochanteric bursitis more than gluteus medius tendinopathy in contrast to other studies. $41.4 \%$ of the patients had trochanteric bursitis alone, $16 \%$ of the patients had gluteus medius tendinopathy alone and $\% 4$ of the patients had gluteal tendinopathy together with bursitis. The results of other studies differ from our study. In the study of Long et al., 877 patients were analyzed with greater trochanteric pain. $8.1 \%$ of the patients had trochanteric bursitis alone, $41.3 \%$ of the patients had gluteal tendinopathy alone and $8.6 \%$ of the patients had gluteal tendinopathy together with bursitis [16]. Differences between the studies may be referred to number of patients. In the study of Bird et. al., gluteal tendinopathy together with bursitis was $10 \%$, gluteal tendinopathy alone was $83.3 \%$ of the 24 patients according to magnetic resonance imaging (MRI) [12]. The difference from our study may be associated with MRI findings of gluteal tendinosis or bursitis are often present also in asymptomatic patients [17].

There are two limitations in our study. It is an retrospective study and it lacks control group. Consequently assessment of physical examination in asymptomatic patients was not performed.

In conclusion, to determine the accurate cause of greater trochanteric pain, both physical examina- tion and ultrasound imaging are significantly important.

Conflicts of interest: There are no conflicts of interest and funding.

\section{REFERENCES}

1. Walsh G, Archibald CG. MRI in greater trochanteric pain syndrome. Australas Radiol 2003;47:85-87.

2. Bard H, Vuillemin-Bodaghi V, Mutschler C. Tendinopathies du moyen et du petit glutéal: étude pilote de critères cliniques. Rev Rhum Ed Fr 2006;73:552.

3. Tortolani PJ, Carbone JJ, Quartararo LG. Greater trochanteric pain syndrome in patients referred to orthopedic spine specialists. Spine J 2002;2:251-254.

4. Gottschalk F, Kourosh S, Leveau B. The functional anatomy of tensor fasciae latae and gluteus medius and minimus. J Anat 1989;166:179-189.

5. Kagan A 2nd. Rotator cuff tears of the hip. Clin Orthop Relat Res 1999;368:135-140.

6. Collée G, Dukmans BAC, Vandenbroucke JP. Greater trochanteric pain syndrome (trochanteric bursitis) in low back pain. Scand J Rheumatol 1991;20:262-266.

7. Adler RS, Sofka CM. Percutaneous ultrasound guided injections in the musculoskeletal system. Ultrasound Q 2003;19:3-12.

8. Weidner S, Kellner W, Kellner H. Interventional radiology and the musculoskeletal system. Best Pract Res Clin Rheumatol 2004; 18:945-956.

9. Connell DA, Bass C, Sykes CA, et al. Sonographic evaluation of gluteus medius and minimus tendinopathy. Eur Radiol 2003;13:1339-1347.

10. Segal NA, Felson DT, Torner JC, et al. Greater trochanteric pain syndrome: epidemiology and associated factors. Arch Phys Med Rehabil 2007;88:988-992.

11. Ege Rasmussen KJ, Fanø N. Trochanteric bursitis: treatment by corticosteroid injection. Scand J Rheumatol 1985; 14:417-420.

12. Bird PA, Oakley SP, Shnier R, Kirkham BW. Prospective Evaluation of Magnetic Resonance Imaging and Physical Examination Findings in Patients With Greater Trochanteric Pain Syndrome. Arthritis \& Rheum 2001;44:2138-2145.

13. Kong A, Van der Vliet A, Zadow S. MRI and US of gluteal tendinopathy in greater trochanteric pain syndrome. Eur Radiol 2007;17:1772-1783.

14. Garcia FL, Picado CH, Nogueira-Barbosa MH. Sonographic evaluation of the abductor mechanism after total hip arthroplasty. J Ultrasound Med 2010;29:465-471.

15. Fearon AM, Scarvell JM, Cook JL, Smith PN. Does ultrasound correlate with surgical or histologic findings in greater trochanteric pain syndrome? A pilot study. Clin Orthop Relat Res 2010;468:1838-1844.

16. Long SS, Surrey DE, Nazarian LN. Sonography of Greater Trochanteric Pain Syndrome and the Rarity of Primary Bursitis. AJR 2013;201:1083-1086.

17. Blankenbaker DG, Ullrick SR, Davis KW, et al. Correlation of MRI findings with clinical findings of trochanteric pain syndrome. Skeletal Radiol 2008;37:903-909. 